\title{
The Place of the Husbands: Masculinity, Male Work and Household Economy in eighteenth-century Italy. The case of Turin
}

\section{Beatrice Zucca Micheletto}

This article investigates the economic role of married men in the family economies of the middle and lower classes of eighteenth-century Turin. In the last twenty years, many studies have dealt with male identity, yet while research on masculinity has flourished in Anglophone and German historiography, the subject has failed to gain ground among Italian scholars. ${ }^{\mathrm{i}}$ One of the most important topics in studies which deal with masculinity revolves around the definition of male authority and the exercise of male power within a patriarchal order. According to many studies, from the Renaissance, the pater familias epitomised manhood. Described in conduct books as well as in family memoires intended for nobles and wealthy families aspiring to an aristocratic life-style, the pater familias was husband and father, capable of managing his assets, economically independent, and able to provide for his family and to clear his debts. These criteria formed the basis of his authority, honour and credibility not only in relation to the members of his family, but also within the social and political arena, where he was a civis, a respectable citizen, able to honestly act for the public interest and carefully manage common resources. ${ }^{\text {ii }}$

A little more than a decade ago, John Tosh was the first scholar to advocate the 
importance of studying the place and role of men in domesticity and upbringing in understanding masculinity. His proposal was a response to the tendency among scholars to hold that 'the proper scope of "history" was defined by the res gestae of the public world', and that in Western societies, masculinity 'has been identified with the disparagement of home comforts, and sometimes with the rejection of home itself' ${ }^{\text {iii }}$ On the contrary, according to Tosh, 'the domestic sphere has always been central to the validation of masculinity'. In Tosh's view, in Victorian England, an adult male would become head of the family as soon as he could establish a household of his own; his position entailed that he could exercise economic and sexual control over the members of his family, while at the same time ensuring their protection. His virility was manifested through fatherhood and the act of passing his property and skills to the ensuing generation. Within this framework, the household was a 'pyramidal' unit of production at whose pinnacle stood the pater familias, with the dependants (wife, children, and cohabitant servants and apprentices) at the bottom. Specific economic relations existed between the former and the latter: all family members worked for the household under the direction and control of the head of the family, who acted 'as head and director of a productive team' ${ }^{\text {iv }}$ It was the father who retained decisional power and controlled the production, organised the labour resources, assigned tasks and administered discipline; while at the same time he was responsible for establishing the connections between the family business and the network of customers and suppliers. A man who fulfilled these expectations gained authority, social recognition and respectability. 
Later research that tackled artisanal groups in pre-industrial societies established the existence of a precise nexus between masculinity and domesticity. In northern Europe, especially in German-speaking areas, manhood, mastery and marriage were interconnected. These links were supported by law, institutions, and social and cultural models. Guilds' regulations required a master to be married; as a matter of fact marriage contributed in marking the difference between masters and journeymen, for the latter were not allowed (or were discouraged) to marry. According to many such regulations, the master had to be a married man, since he needed the help and collaboration of his wife and children in the workshop. Yet, an artisan could marry only upon acquiring mastery, when he was presumably able to provide for his family ${ }^{\mathrm{v}}$. Mastery and marriage, therefore, should mark the passage from a condition of subordination and dependence to one of autonomy and responsibility. The achievement of economic independence was peculiar to the head of the household: this conferred to him authority and confirmed his leading position over his subordinates (women and the other males of the family, be it apprentices, journeymen or servants). In several areas, economic independence also entailed the acquisition of citizenship, which implies that the man gained the right (and the duty) to participate and take decisions in matters pertaining to the community.

However, in everyday practice, the relationship between masculinity and professional paths were more blurred not only because marriage restrictions did not concern all the crafts, but above all, because the ban did not prevent journeymen from getting married, even if in 
the majority of cases they suffered discrimination, marginalisation and even violent attacks from masters and other unmarried journeymen. Specifically, in Early Modern Germany unmarried journeymen developed their own ideal of masculinity based on the rejection of marriage and on a set of values that exalted 'transience, prodigality, physical bravery, and comradeliness' as the foremost virtues of the true man, 'in sharp contrast to the masters' virtues of thrift, reliability and stability' ${ }^{\text {vi }}$

In sum, if we focus our attention on the economic role of the married man, we can conclude that, at least in theory, as head of the household, he was expected to be economically independent, to be the main provider for the family and the leader of the domestic unit. This representation was based upon two (more or less explicit) premises: firstly, male labour, its organisation and the circumstances under which it was performed, was stable and men, in normal conditions, were able to count on regular work and income; secondly, the head of the household had easy access to the resources of the family and of his subordinates (especially his wife's) and was free to manage them. These points cannot be taken for granted and uncritically applied to different social, economic and cultural contexts.

According to Natalie Zemon Davis' and Joan Scott's pioneering studies, gender is a useful category of analysis also because it allows us to question the stereotyped social and cultural construction of both men and women. As a consequence, research on masculinity should go beyond these models of manhood with the aim of testing their limits of applicability and evaluating to what extent they represented ideological constructs as opposed 
to the concrete experience of adult men. In other words, focusing on my case study, was the pater familias model pertinent to describe the idea of masculinity of Turinese inhabitants of all social and professional backgrounds, or, on the contrary, was it in competition with other cultural and social models peculiar to specific groups? And did the same prescriptions of northern European guilds apply to the Turinese case? The aim of this paper is to precisely investigate, how married men belonging to middle and lower classes in eighteenth-century Turin participated in domesticity by exploring the nature of male work and the real extension of their control over their family's and wife's resources.

In the last years, several studies have highlighted the diversity of male labour patterns. Some of them have shown that learning and training paths were often irregular, and that exchanges and collusion among guild members and outsiders were possible. ${ }^{\text {vii }}$ Others have pointed out the great mobility and turnover of the labour force in craft shops. ${ }^{\text {vii }}$ However none of these studies has taken advantage of this evidence in order to find nuances in the typical depiction of the economic role of the pater familias and to establish the limits and constraints of his role as the main provider of his family's well-being. ${ }^{\text {ix }}$ Recent research has partially mitigated this model. In studying connections between manhood and credit among the lower and middling ranks of early modern Cambridge, for example, Alexandra Shepard has pointed out that even if the economic autonomy of married men was part of a powerful patriarchal discourse, it was also a 'privilege which many men could not afford'x ${ }^{\mathrm{x}}$ since the majority did not have resources or full control over them. In addition, in a more indirect way, 
during the last twenty years, studies of female property in preindustrial Italy, where a dowry system existed, have provided evidence of the fluid - and even limited - nature of the authority of the pater familias. There, the husband was legally responsible for his wife's dowry: he had the right to manage it during the marital life, but at the same time he had the duty to integrally preserve it in the interest of his wife, a fact which established a severe limitation to his power over his wife's assets. ${ }^{\mathrm{xi}}$

Taking into account these studies, the present article will analyse different archival sources providing information on the features and conditions of married men's work in order to verify whether they confirmed or challenged the traditional representation of adult men as 'head of the domestic team' and provider for their 'dependants'. At the same time it will inquire into the authority and independence of married men in managing the economic resources of the domestic unit. Of course, these issues are relevant not only for married men. In a recent research, Sandra Cavallo has explained that in early modern Turin surgeons achieved mastery before getting married, while others ran thriving shops, were appointed to public office and enjoyed respectability and influence while remaining bachelors. ${ }^{\text {xii }}$ This study will deal specifically with married men and will analyse the role of their paid work within the household economy, as well as the extension of their control over the family's and wife's resources. On the base of the archival material I have analysed, I will suggest that the economic role of husbands and fathers was more complex and contradictory than the model of the pater familias leads us to presume. Moreover the article argues that among the middle 
and lower classes this model was mitigated and called into question not only by practice but also by an alternative family model based on the idea that every member of the household including the wife and children - had to provide for their own and for the household.

The article is organised as follows. In the first two sections (Husbands and fathers in economic difficulty and Marital life and professional life) I will investigate the husband in his function as main provider and economic leader of the household. Applications by poor families to the Ospedale di Carità (the most important charitable institution in Old Regime Turin $^{\text {xiii }}$ ) and a set of petitions from Turin-based artisans will offer evidence of the economic difficulties adult men had to face during their marital life. They will especially show how male work was irregular and uncertain, and affected by professional and geographical mobility, thus betraying the myth of the economic independence and solidity of the pater familias. In the sections Hierarchical economic roles and Independence or dependence the tasks of married men will be studied within the wider context of the household. I will then show that husband and wife performed complementary rather than hierarchical economic roles in the labour market, and will suggest that the husband was far from being the economic leader of the family. As data collected from petitions for dowry alienation clearly show, marriage did not guarantee the opportunity for a man to freely handle either his inheritance and assets or the resources brought by his wife into the new domestic unit. Finally, the fifth section, The duty to provide for one's family will inquire into the influence of the ideals of masculinity and femininity as well as social expectations upon behaviour. More specifically, 
it will show that among middle and lower groups the pater familias model was in competition with the idea that, independently from gender ideologies, every member of the household had mutual obligations of solidarity and support.

\section{Husbands and fathers in economic difficulty: evidence from the Ospedale di Carità}

According to a traditional ideological construct, one of the most important duties expected from the husband was to be the main provider of his household. I will discuss this point by using the registers of the applicants of the Ospedale di Carità. During the eighteenth century, Turin was the capital of the Duchy of Savoy (later the Kingdom of Sardinia) and a middlesized city (its population grew from more than 60,000 inhabitants in 1754 to about 70,000 after 1781). ${ }^{\text {xiv }}$ Domestic services and crafts were the cornerstones of the economic structure employing more than half of the population. According to the census of 1802,42 per cent of the working female population (aged 15 and over) and more than 38 per cent of the working male population were employed as domestics, waiters and waitresses, cooks, coachmen, grooms, porters, laundresses and ironers, while about 33 per cent of women and 38 per cent of men worked in crafts (silk weavers, shoemakers, carpenters, ribbon-makers, sock-makers, etc.). ${ }^{\mathrm{xv}}$ They mostly produced and sold luxury goods to the upper classes - from the aristocracy at the royal court to the wealthy merchants and bankers, from the religious hierarchies to the army. Like in many other European cities, in Turin there were wellestablished hospices and charitable institutions. Despite anti-vagrancy statements, the policy 
of the Ospedale di Carità was to provide relief to a wide range of people in economic distress: poor, elderly, ill, single people and orphans were housed in the institution itself, while families received rations of bread, and their babies were cared for by wet nurses paid by the hospital. The crucial role played by the Ospedale in supporting poor people and families increased in the second half of the eighteenth century, when impoverishment and proletarianisation had a detrimental effect on the standards of living of the majority of the population.

By that time, the artisanal system, mostly based on the production of silk yarns and silk clothes, was going through a crisis. Taking inspiration from the principles of mercantilism developed by Colbert in France, the king and his ministers explicitly supported silk activities. ${ }^{\text {xvi }}$ From the end of the seventeenth century, important investments were made in the production of silk yarns, mostly in the Piedmontese countryside, and in silk manufacturing in the city, where numerous artisans produced these commodities (cloths decorated with gold or silver yarns, ribbons, trimmings, socks, buttons, etc.). However, in the second half of the eighteenth century, silk production was hampered by frequent poor harvests due to bad weather conditions (e.g. in 1777 and 1787), while silk fabrics suffered from competition with new textiles such as cottons and other printed 'exotic' cloths. ${ }^{\text {xvii }}$ As a consequence, silk spinners and silk weavers were often out of work. Broadly speaking, all the Turinese artisanal sectors were affected by social and economic tensions: there were violent internal conflicts between guilds for the control of the labour force and for the monopoly of 
production, as well as altercations between small masters and the oligarchy of large merchant-manufacturers who were seeking to concentrate the trades in their hands. By that time, 'journeymen were reduced to the condition of casual worker or day-labourer, masters were employed as wage-earners, and mere apprentices carried out work [that was] previously domain of journeymen'. ${ }^{x i i i}$ In the meantime, prices of cereals and foodstuffs increased despite the effort of the authorities to keep them under control. In 1766, the wheat crop was badly stricken by drought, and in 1772 it plummeted to a mere one third of the normal production level, while in 1785 an epizootic decimated cattle in the countryside around Turin. In all cases, the result was a serious shortage of food for the urban population and a staggering increase of prices. ${ }^{\mathrm{xix}}$ In this context, therefore, it is not surprising that applications for public relief at the Ospedale rose (figure 1).

Fig. 1 Number of annual applications for relief to the Ospedale di Carità (1766-1792)

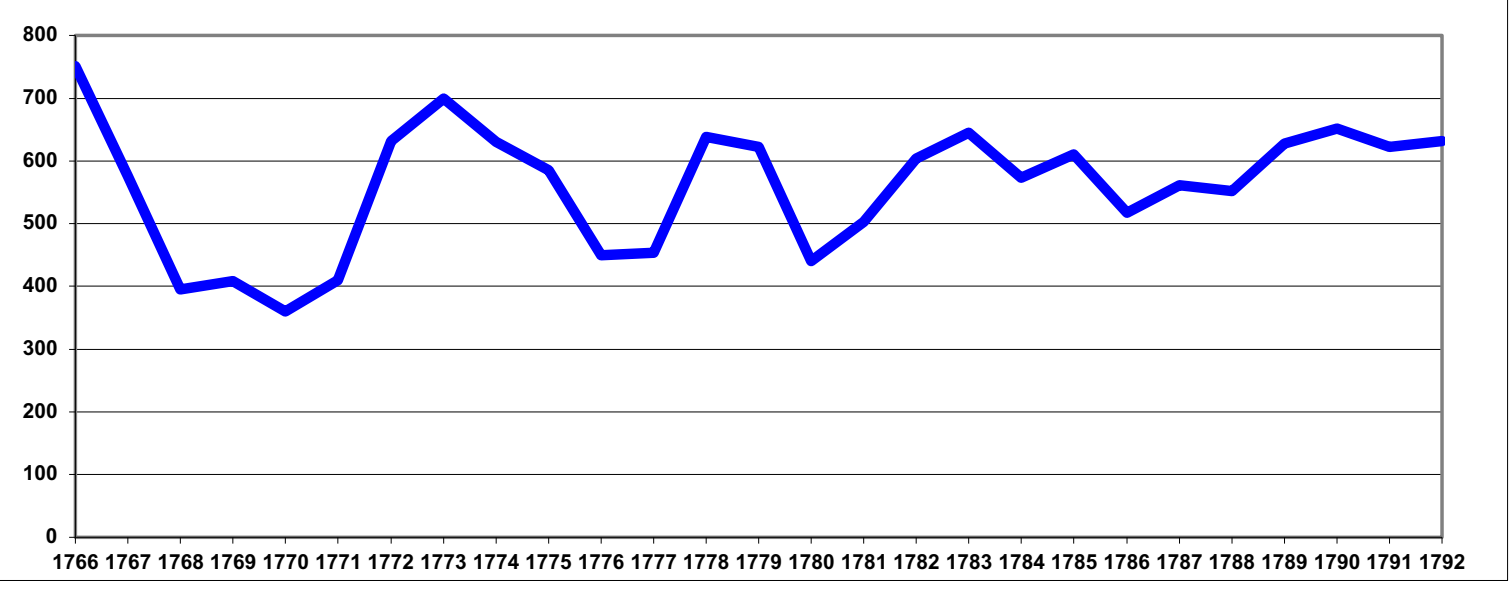


Individuals and families were recorded in the Libri delle Informazioni: people stated their age, profession, place of birth, marital status, and domicile in the city and explained their predicaments. Generally, the Ospedale would provide relief to anyone in need for several years. Every six months the institution would make household checks in order to verify any changes in the situation of poor families. Between 1766 and 1792, 47.4 per cent of all adult men and 30.7 per cent of all adult women applying for relief worked in crafts or manufacturing. In addition, 30.2 per cent of all male applicants and 22.9 per cent of the female applicants were employed in domestic service.

Data from the Ospedale provide strong evidence that adult men, husbands and fathers, were not always able to cover the responsibilities attributed to the head of the household. Indeed, this charity institution helped not only individuals from those categories which were traditionally viewed as more susceptible to poverty (widows, orphans, and foundlings): an important amount of relief was granted to couples, most of them with children and babies. As shown in the following table, during the period under analysis, about 38 per cent of applicants were couples and 6.9 per cent were married women, whose husband was temporarily absent or else was estranged (table 1). The Libri delle informazioni, reveal that in the second half of the century, many adult men had a discontinuous and unstable relation with the labour market and, for this reason, they were not able to provide a regular income, a responsibility which was often considered such a specific feature of the male identity. Moreover, most of them were neither bachelors nor widowers, neither too old or ill to work, 
nor lacking social resources; they were husbands and fathers, heads of households, in obvious economic straits.

Tab. 1 Requests for relief according to the family condition of applicants at the Ospedale di Carità (17661792)

\begin{tabular}{|l|r|r|}
\hline & & \multicolumn{1}{l|}{$\%$} \\
\hline couples & 5690 & $\mathbf{3 8 , 1}$ \\
\hline widows & 2979 & $\mathbf{2 0 , 0}$ \\
\hline widowers & 1179 & $\mathbf{7 , 9}$ \\
\hline & & \\
married women without husband & 1030 & $\mathbf{6 , 9}$ \\
\hline married men without wife & 89 & $\mathbf{0 , 6}$ \\
\hline unmarried women & 1031 & $\mathbf{6 , 9}$ \\
\hline unmarried men & 890 & $\mathbf{6 , 0}$ \\
\hline $\begin{array}{l}\text { abandoned children, foundlings } \\
\text { and orphans }\end{array}$ & 1185 & $\mathbf{7 , 9}$ \\
\hline without indication & 858 & $\mathbf{5 , 7}$ \\
\hline & & \\
\hline total & 14931 & 100 \\
\hline
\end{tabular}

Source: ASCT, Ospedale di Carità, Libri delle

Informazioni per ricoveri, vol 38-49

In addition, about 3 per cent of the married men applying for relief who had a job (i.e. 205 individuals out of 6,809) did not hesitate to present themselves as 'fallen' (decaduto) or 'destitute' (senza fondo), and another 2.7 per cent declared themselves 'out of work' (senza travaglio). Francesco Trucchi, for example, married with two children, justified his application by explaining that he was a 'longstanding shoemaker' obliged to close his shop 
because of a lack of means. ${ }^{\mathrm{xx}}$ While Pietro Francesco Ghigliano, married with four children, presented himself as a 'former hat-maker with workshop, nowadays gone bankrupt'. ${ }^{x i}$ The Ospedale helped families to get through a critical economic situation: aid was meant to be temporary and aimed at encouraging individuals to re-enter the labour market. Yet applications show that the head of the household did not hesitate to leave (temporarily or definitively) the family, whether to search for work abroad, to enlist in the army or else in an attempt to escape from creditors. Gio Battista Cebrani, a 25 year-old carpenter, married with a child, left Turin in 1778 because he was 'overloaded by debts', while his young wife Orsola, employed in canvas sewing, obtained different kinds of help from the Ospedale until 1792. ${ }^{\text {xii }}$ In February 1779, Gio Domenico Tignard, a journeymen cloth-weaver aged 52, married and father of three children, moved to the community of Pinerolo (in close proximity to Turin) 'to find work', since he was jobless, while his wife, a waitress, applied to the Ospedale. ${ }^{x i i i}$ Sometimes the head of the household was absent because he was imprisoned. Gioanni Domenico Golio, for example, a journeyman boiler and pot-maker, was imprisoned in January 1784. Four months later, his wife, Maria Domenica, a foodstuff retailer, asked for relief for herself and their four children. According to the registers, she received help until 1790; meanwhile, the husband never returned home and in December 1789 Maria Domenica declared herself a widow. ${ }^{\text {xiv }}$

Applications to the Ospedale clearly show that husbands and fathers could not always fulfil the expectations that the accepted social models had set for them. Of course they 
participated in the family economy, but their contribution might be insufficient and discontinuous. Their relation with the labour market was often difficult: work was irregular and did not ensure a stable income while the rhythms of work and production changed in the course of the seasons and years. Due to these conditions, the demand for labour became uncertain and unstable, a fact which made economic investments risky: shortage of work was frequent, while turnover or bankruptcy occurred in all economic sectors. For many artisans and shopkeepers, therefore, the possibility of opening a shop vanished and they had to fall back on cottage manufacturing, many went from an independent activity to a salaried job, and even from one job to another. A few cases among the multitude of applications to the Ospedale serve to illustrate this unstable situation which forced artisans to leave the trade they were trained in: in 1776, for example, a former wig-maker then servant, father of a baby, sought help from the institution. Similarly, in 1778, a former silversmith, who was later employed in pottery but lost his job applied to the Ospedale, since he had to support his wife and three children. An application dated 1783 illustrates the case of a former journeymen furrier who subsequently worked in the paper business, while his wife was employed as a seamstress. This 'forced flexibility' applied also to several silk-weavers: among the applicants one left his former job and enlisted in the army while another was employed as a coachman. ${ }^{\mathrm{xxv}}$

In sum, in the last decades of the eighteenth century, the capacity of husbands and fathers to support their family in a stable and continuous manner was called into question: 
adult men lost their jobs, were obliged to change or pursue different economic activities and to ask for poor relief. However, the discontinuity and instability of the male employments were not limited to the period of economic and social crisis which typified the turn of the century. Surely this was a moment in which contradictions became more marked, but there was nevertheless a specificity of the Turinese local labour market that cannot be ignored and that will be tackled in the next section.

\section{Marital life and professional life}

According to works by contemporary scholars, in several European contexts of the past the head of the family was supposed to act as the economic leader of the household and as the head and director of the family (understood as a productive unity). ${ }^{\mathrm{xxvi}}$ Especially in early modern Germany these characteristics were considered the exclusive domain of masters since, at least in theory, in guild regulations, marriage and mastery were linked. In addition, this cultural and social model established a dichotomy between the master, associated with economic independence, and the journeyman, who lacked such autonomy. ${ }^{\text {xvii }}$ I will examine the reliability of these arguments with reference to a set of petitions sent from the artisans of the city to the king in the eighteenth century. The data show that an excessively rigid division between masters and journeymen did not characterise the experiences of male artisans during the historical period under consideration.

During the first half of the century, the craft guilds in Turin were renewed and strengthened on the initiative of their officers: their regulations were re-printed, new norms 
and limits were added and earlier privileges were upheld, while a strict control on the professional paths and turnover of the labour force was enforced. ${ }^{x x v i i i}$ Nonetheless, throughout the second half of the century, artisans, already struggling with economic hardship, tried to gain access to the guilds, to obtain permission to open a shop or perform the trade even if not in possession of all the necessary requirements, or to get a significant reduction on membership fees and/or exemption from presenting their masterwork, considered too expensive, by addressing petitions to the king. These petitions - addressed by artisans of both sexes - concerned the most representative of all the crafts that were practiced in Turin. For this article I will refer to the petitions addressed to the authorities by shoemakers, brandy- and candy-makers, sock-makers, wig-makers, hat-makers, silk weavers, ribbon-makers and button-makers, during the second half of the eighteenth century. ${ }^{\text {xxix }}$ Artisans retraced their professional careers and learning paths; they explained how and where they started to perform the trade and why they were worthy of being admitted into the guild. Recent studies have shown that petitions should be approached with caution, since they usually employed a specific linguistic register, tailored to legitimate the position of the petitioners and their requests. For example, artisans frequently referred explicitly to their role as providers and to their duty to ensure the survival of the family. They could emphasise their long-standing experience in the craft, their presence in local networks as well as the good reputation they had acquired. All of these arguments, of course, could correspond to real situations, but they were also deployed to legitimise requests, and in order to resonate with 
official expectations. Moreover, in an effort to prove that they had in fact tried to support their families, the petitioners would supply descriptions and linger on details concerning their daily occupational and family life: these provide important evidence of the fluid economic role of married men. Women too were involved in petitions on their own behalf and I will return to their claims below.

The petitions show that artisans could marry and create a family, despite being employed as journeymen. In 1767, Giuseppe Rinaldi, a 55-year-old shoemaker, explained that he had been a journeyman for 25 years, and also that he was married and had a child..$^{\mathrm{xx}}$ Similarly, Daniele Auda had been employed as a journeyman wig-maker in the shop of the Lyone family for 23 years, during which he got married and fathered two children. ${ }^{\mathrm{xxx}}$ While Felice Tribaudino, aged 36, was married but he was still a garzone (journeyman) in the shop of Gio Machioletto, a hat-maker master, under whom he had been employed for at least ten years. Within this context, it happened also that the married artisan did not share the same roof with his wife, but, out of choice or constraint, cohabited with the other dependents in the house of the master. Biaggio Fissore, a 45-year old, married artisan, was employed as a garzone in a shop producing and selling spirits and confectionery. He was registered as a cohabitant in the shop of his master, while no mention was made of his wife, who, clearly, did not live with him. A similar case concerns Antonio Allaria: at 36, although married, he was still a garzone and lived in the house of Gio Angelo Core, a spirit-maker master owner of a shop. ${ }^{\text {xxxii }}$ It follows that marriage was not necessarily connected to the achievement of 
mastery and establishment of an independent household.

At the same time, the condition of garzone did not necessarily coincide with a state of subordination and dependence nor with economic destitution. As Sandra Cavallo's research on Turinese barbers and surgeons clearly shows, salaried work in a shop could involve positions of responsibility and de facto partnerships between master and journeyman, and in some cases the status of garzone could become a permanent condition. ${ }^{\text {xxxiii }}$ The documentation under analysis clarifies that a married man could be obliged to continue working indefinitely as a journeyman despite having the competencies and resources to own a shop (or having already opened one), if he did not fulfil the necessary requirements imposed by the guild for acceding to the mastery. Lorenzo Gazzola, a married man and an experienced spirit-maker and candy-maker active around 1751, was part of an important professional network that had enabled him to work for the royal court. Nonetheless he was prevented from moving beyond the status of journeyman, because he did not complete a regular apprenticeship as prescribed by the guild. However his abilities were praised even by a colleague who observed how Lorenzo was 'capable and expert in working as a spirit-maker, distiller of brandy and preserve-maker (...) and in preparing, buying, selling and trading [these products] as well as coffee, chocolate and refreshments, in sum, to do everything that all that the masters of this city are used to do' ${ }^{\text {xxiv }}$ Analogously, Gaspare Silvestro, hat-maker and hat trader, married since 1758, had a long experience in the sector and had travelled abroad in order to improve his skills. Despite his efforts, in 1764, he had not yet achieved 
mastery and was therefore compelled to pay a master officially acknowledged by the guild in order to manage the shop on his behalf. ${ }^{\mathrm{xxx}}$ It is likely that in these cases, the artisan who was denied the status of master did not perform the tasks usually assigned to journeymen, but with all probability, managed, took decisions and organised the work as the actual owner of the shop.

The professional paths of Turinese artisans were further characterised by a certain degree of professional mobility. Artisans were not invariably tied to the craft they were trained in, rather, they could move from one trade to another. Carlo Felice Carpano produced and sold brandy in his shop in Orbassano (in the proximity of Turin) but 'because of hard times and high price of foodstuffs' he was forced to close his shop and move to Turin, where he found employment in 'tinting fabric and paper'. ${ }^{\text {xxvi }}$ This job mobility was part of a common survival strategy known as pluriactivity: artisans switched from one trade to another or else were employed in multiple activities according to labour demand. ${ }^{\text {xxxvii }}$ Pluriactivity allowed people to bypass periods of shortage of work or to supplement low incomes. From this perspective, the case of Gio Maria Croce, who in 1759 was striving to open a shoe shop in Turin, is representative. A native of Savona, where he ran a cobbler's shop, Gio Maria boosted the revenues from his main activity by working three days a week in the local pawnshop, where he received a salary of 300 livres per year and was given a room for his family. ${ }^{\text {xxxviii }}$ Giuseppe Mya's profession as a barber and wig-maker did not deter him from producing and selling ribbons as a modest retailer in the suburb of the city. ${ }^{\text {xxxix }}$ In many cases, 
of course, artisans did not really abandon their previous craft to start a completely new one, but they were ready to accept similar jobs. Bartolomeo Millié was skilled in the construction and maintenance of looms for silk sock-makers but, in the absence of work, he petitioned the king in the hope of obtaining mastery as a blacksmith (serragliere) and thus increasing his income. ${ }^{\mathrm{xl}}$ Similarly, Gio Batta Bogetto was a basket and sieve-maker, but he was also an able lathe turner (tornitore). ${ }^{\mathrm{xli}}$

To a certain degree, professional mobility can be explained by the fact that in preindustrial societies activities were less fragmented than contemporary scholars tend to present them in their analysis of occupations, that is by resorting to 'functional categories (i.e. service, retail) or categories based on the raw materials of production', which are completely disconnected from a particular context. ${ }^{\text {xlii }}$ On the contrary, professional categories encompassed artisans and professionals that, in performing apparently different but overlapping or related trades, shared common competences, values and tastes which the rigid classifications usually used by scholars tend to conceal. Throughout their professional path, artisans acquired a range of skills that could be easily adapted to perform (apparently) different activities. Bartolomeo Zucca in 1792 was registered as a journeyman in the service of a pastry-maker, but ten years later he traded in flour and bran, while Gio Domenico Serralunga, a former spirit-maker, moved to wine trading. ${ }^{\text {xliii }}$ This aspect was very common among artisans involved in manufacturing goods and selling raw material, as, for example, Bartolomeo Moggio, registered in the artisan census of 1742 as both a merchant of cereals 
and a baker. ${ }^{\text {liv }}$

The professional mobility among these petitioners is particularly striking when considering the artisan group since specialisation in one's craft and professional stability were held as the salient characteristics of respectable craftsmen. ${ }^{x l v}$ It is likely that several Turinese artisans fulfilled these expectations: indeed, in their petitions they emphasised their long experience and their roots in local networks, proven by depositions from well-reputed colleagues. At the same time, data provides evidence of the fact that their professional status was complex and fluid, since they could be involved in (and adapt to) different economic roles. Even if the period of economic crisis highlighted these incongruent careers, all these contradictory aspects of their identity were particular features of the Turinese labour market in the eighteenth century which remained constant well beyond the times of hardship. Furthermore, in contrast to what happened in many other European cities, these married artisans - lacking a mastery and their own business, but responsible for providing for their children - did not attract blame or dishonour. Nor did their 'irregular' conditions prevent them from presenting their case, before the authorities, emphasising their skills as well as their role as providers. On the contrary, these arguments were used to strengthen their request. Gio Bartolomeo Forlino, a hat-maker, had been a journeyman for nine years during which he got married and had three children. In 1764 he sent a petition to the king in order to obtain mastery without presenting his masterwork and explaining that he wished to run an independent shop 'since at the present, he earns only 20 livres a day', a wage which was too 
meagre to enable him to sustain his family. ${ }^{\text {xlvi }}$ Similarly, the already cited Gio Maria Croce, a shoemaker and employee at the pawn shop, and Bartolomeo Millié, a loom-maker and blacksmith, did not hide from the authorities their professional mobility, since they considered this as a proof of their efforts to ensure the well-being of the family.

Petitions sent to the King and preserved in the registers were always successful (therefore we don't know whether all petitions were successful or the unsuccessful ones were not preserved). The artisan provided with the royal patent had to appear before the judges of the Consolato di Commercio (the civil court that dealt with disputes within the guilds and on matters concerning labour) and presented a simplified/cheaper version of the masterwork or underwent an oral examination. Only at this stage could an artisan's request be rejected by the judges, if his command of the craft was deemed insufficient. At any rate, neither the king nor the Consolato, ever denied a request because of marital status: as opposed to their north European colleagues, therefore, Turinese married journeymen did not encounter hostility on the part of the authorities and institutions.

\section{Hierarchical economic roles? Husband and wife at work}

At this point of the inquiry, we should evaluate the consequences of irregular and unstable work conditions of the head of the family on the economic roles of the spouses within a household and more specifically gauge if this affected the balance of power between husband and wife. In the last 30 years, women's studies have shown that women performed paid and unpaid work in almost all economic activities and sectors. Of course, a survey of this 
abundant literature is not within the parameters of this study. ${ }^{x l v i i}$ For the purposes of this article, I will concentrate on a specific aspect: the fact that the work performed by wives was neither merely integrative nor secondary to the craft exercised by the head of the household. Since the pioneer work by Alice Clark, scholars tend to propound that within artisan families, wives were expected to work as subordinates, under the direction of their husbands. ${ }^{\text {xlviii }}$ This meant that the relationship between husband and wife was strictly hierarchical, with the husband retaining the leading role. When considering eighteenth-century Turin, though, this axiom ought to be questioned for it is clear that the economic role of the wife was far more complex. This is not to deny that women played an active role in supporting their family business; yet the woman's contribution was not necessarily based on a hierarchical relation between the spouses. ${ }^{\text {xlix }}$ First, when the wife worked directly in the family business she often invested her dowry in the activity and held a share in the ownership of the shop and/or the tools and furnishings, a fact that could give her more leeway within the relationship (I will consider this point in the next section). Otherwise, the wife could perform an independent or semi-independent craft, often related to the trade practiced by her husband. The case of Anna Bossi provides a typical example: a mastra (mistress) taffeta and silk-weaver, it is very likely that Anna participated in the marital production of silk-hoses, since both the activities needed looms and silk yarns and catered to the same clientele. ${ }^{1}$ Similarly Cristina Maria Podio, who owned and ran a shop selling women's clothes and fashion accessories (mercante da moda), probably shared the same client network as her husband, who manufactured and sold shoes in 
his shop. ${ }^{\text {li }}$ Thus a wife may have some kind of independence without being in a subaltern position in relation to her spouse. Finally, the economic position of the married woman as a 'subordinate' of the husband did not apply to the wives of salaried journeyman who, naturally enough, were employed in economic activities which bore no relation with the trade of their spouses.

At any rate, the applications to the Ospedale di Carità reveal the crucial economic role played by women and clarify that the earnings of both partners were necessary for the survival of the family. Between 1766 and 1792 about only one third of couples (36.5 per cent) shared the same activity, i.e. 378 out of the 1,035 households. ${ }^{\text {lii }}$ This means that for the majority of couples - whether running their own independent activities or working as employees - the allocation of tasks to be performed within the business was based on a logic of diversification and complementarity. In addition, if the husband was out of work, absent or invalid, the responsibilities for the family fell exclusively upon the wife. It is therefore not surprising that female artisans used petitions as well in order to apply for an exception to guild rules asserting their crucial economic role in the household before the authorities. In 1756, Carlina Olivetta explained that she was employed in making and selling ribbons for children's clothes because her husband - a former trader in furs - had gone bankrupt and was obliged to accept a job as a journeyman. ${ }^{\text {lii }}$ While Maria Negro, wife of Giuseppe Cora, stated that she had been working in silk buttons for 22 years, in order to provide for herself and her eight children, since her husband had a low income as a servant. ${ }^{\text {liv }}$ In 1787 Rosa Melano, 
married with children, a silk weaver with a mastery for manufacturing pinstriped taffeta, obtained by the Consolato the right to produce and sell simple silk cloths (e.g. gauze) for the merchant-bankers since her husband had left the kingdom and her income was insufficient. ${ }^{\text {lv }}$ All the petitioners emphasised their productive role when exposing the economic difficulties of their families. However, we cannot assume that married women from middle and lower classes entered the labour market due to the sheer necessity of the moment. Obviously, if a wife could improvise and seek a job as a retailer or a servant, the same cannot be said for crafts which required both a certain degree of specialisation as well as a network of clients and suppliers. As a consequence, the crisis which engulfed Turin and Piedmont in the second half of the eighteenth century does not explain the involvement of married women in the labour market: their presence made its weight felt well beyond this specific economic conjuncture. Moreover, the manner in which women performed their work, in the family business as well as in more or less related activities, reveals that they were not always merely in a subordinate position to their husbands. In Old Regime societies, according to pedagogic and religious models the 'natural' role of a woman was to be a wife and a mother, while female work was considered such as a service rather than the result of specific abilities and competencies. As a consequence women were never considered as workers, whether performing paid or unpaid activities. Because of these ideas, on the one hand their work had no or little social acknowledgement and they were condemned to be an almost invisible labour force. On the other hand, however, the importance of the wife's work was emphasised 
by women themselves and even by the authorities, especially in situations of economic malaise, when the gender-based hierarchies established by accepted social models could be temporarily suspended, as the aforementioned cases clearly demonstrate. ${ }^{\text {lvi }}$

The evidence, therefore, sheds doubt on the rigid and hierarchical representation of labour relations between the spouses. Of course, both partners had as a main aim the protection of the family from impoverishment and social destitution, but the wife did not merely perform an integrative activity within the household business. On the contrary, she could 'collaborate' with her husband through an independent or semi-independent activity, and the spouses could share the same professional and social networks as well as competences and tastes. In addition, in the crisis stricken context under analysis, the economic roles of both partners were liable to change and adjust: the spouses' presence in the labour market could alternate, they were forced to regulate their roles according to labour demand and had to face instability and uncertainty.

\section{Independence or dependence? Men's (and women's) resources}

A third set of sources - dowry alienations - further supports the argument that in eighteenthcentury Turin the economic role of husbands/fathers in domestic life was more problematic than the pater familias model seems to suggest: for men marriage did not always mark the acquisition of full control and management of his family's and his wife's resources.

Since the Middle Ages and until at least the nineteenth century, in areas under Roman law, the dowry was considered indispensable for girls from every social group in order to find 
a (suitable) husband. In eighteenth-century Turin the dowry, provided by the bride and her family, was stipulated in a notarial deed, the endowment act. The dowry was composed of two parts: a sum of money, usually paid in cash or with credit or a private deed (more rarely with immovables), and the 'marriage trousseau' which consisted of clothes, linens and furnishings. ${ }^{\text {lvii }}$ Since Roman times, the dowry had been an inalienable female property. A norm contained in Justinian's civil code, further prescribed that it was intended for the economic sustenance of the family ('ad sustinenda onera matrimonii'). ${ }^{\text {lviii }}$ Taking inspiration from this principle, the Regie Costituzioni of the Piedmont (a collection of contemporary and past royal decrees, enacted for the first time by Victor Amadeus II in 1723) stated that couples could be allowed to alienate the dowry through a juridical procedure (the alienazione dotale) and a special authorisation, which enabled them to convert it into money and employ it for the well-being of their family. ${ }_{\text {lix }}$ I will base my arguments on a set of 188 trials for dowry alienation that took place before the Turinese Giudicatura court between 1760 and 1780 . While traces of dowry alienation have been found in the Turinese archives since the beginning of the eighteenth century, this procedure became more frequent during the second half of the century. By that time, the uncertainty of the labour market and a generalised impoverishment of the population made the dowry an indispensable resource for the family's

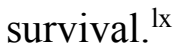

The data set which has been analysed reveals that members of all social groups sought alienation, but the majority who resorted to this procedure hailed from craft, retail and trade. 
Moreover, the notarial deeds which were set up at the end of the procedure and payment receipts reveal that 131 over the 188 couples who appealed to the Giudicatura used the dowry money without delay, immediately after alienation was granted, while the remainder of couples (57) merely kept the sum. The first group of spouses (131) used the sum for three, main (though not exclusive) purposes: firstly to take over or open a shop/inn or to pay suppliers for goods or items for their commercial activity (42 per cent); secondly to pay back money to private creditors, especially charges and daily expenses for survival (90 per cent); and thirdly to redeem clothes, linens and jewels from the city's pawnshops (17 cent). ${ }^{\text {lxi }}$ The procedure for alienation would start with a petition which the couple addressed to the king, in which the spouses exposed their situation and explained the reasons for the request. The details about chronology and modalities of endowment and inheritance, as well as about family and work life contained in these pleas, offer abundant and precious material about both partners and their respective birth families. Moreover, these petitions show that married men, already in dire economic straits due to low income or a shortage of work, did not have full control over their means, and economic matters were therefore awkward. In 1777 Gio Batta Isnardi, a jeweller, explained that his father's estate was modest and debt-ridden; the same reason compelled Bartolomeo Costamagna and his brothers to reject their father's estate. ${ }^{\text {xii }}$ Pietro Bresso, whose case is illustrated in a document dated 1775 , could not yet benefit from his parents' bequests, since he was involved in an on-going juridical action. Felice Martinone, who cohabited with his mother and brother and worked with them in their 
shoemaker's shop, at the time of leaving his natal house with his wife around 1778 had no means, as the family's estate had not yet been divided among legal heirs. ${ }^{\text {lxii }}$ These petitions therefore clarify that men might marry before they had achieved economic independence. It could happen, for example, that the spouses shared the house and worked with the husband's family, as was the case for the aforementioned Felice Martinone and his wife, or Domenico and Benedetta Riccio. The latter, after their marriage, cohabited with Domenico's father and worked with him in his bakery, until they were obliged to leave ('separarsi di abitazione e di mensa') because of the economic difficulties of the father. ${ }^{\text {xiv }}$ Moreover a married man, whether cohabiting or not with his parents or relatives, could be juridically dependent on his close kin and in a state of subordination. According to Piedmontese law, legal majority was reached at 20 years of age; nevertheless, only an official act of emancipation released the son (until then figlio di famiglia, i.e. 'son of the family') from the patria potestas of his father, thus marking the economic and legal separation of the former from the latter. Thereafter, the son became responsible for his own debts and bankruptcy as well as for his wife's dowry; he could act as guarantor for a third party and he could keep for himself the income of his work. However, if the emancipation did not take place, the son - even if adult, married and a father himself - would remain under his father's authority, until the death of the latter. Sandra Cavallo has demonstrated that, significantly, in Turin between the seventeenth and eighteenth centuries, emancipation took place relatively late among artisans, after a man married and had children. ${ }^{1 \mathrm{xv}}$ 
These considerations on inheritance and property management furnish further evidence on two issues. First, they clarify that the husband was far from being the uncontested economic leader of the family and that, for an adult man, marriage or fatherhood did not necessarily entail independence. Secondly, the aforementioned cases explain why, for many couples, the only resource available during the first years of marriage was the dowry. By resorting to dowry alienation, artisans, traders and retailers were able to acquire the necessary capital to invest in the family business, on which the dowry remained guaranteed. In this context, therefore, the wife was not simply a subordinate, but the owner (or, as the case may be, co-owner) of the shop. In some cases couples constituted a legal society that testify to the fact that the wife was legally recognised as the co-owner of the shop, such was the case for Mattia Ludovico Brunel and his wife Adelajde Delfina, who ran a jewellery shop in together 1784. ${ }^{\text {lxvi }}$ Consequently, there were probably limits to marital authority, since the husband could not manage the shop or take decisions without his wife's consent. It is likely that the investment of the female property in the shop and the work tools strengthened the wife's importance and power within the household economy. At the same time, these cases confirm once again, the complexity of the husband's economic role. In the more extreme cases, the husband was indeed in a condition of full dependence to his wife's goods and assets. ${ }^{\text {xvii }}$ Secondly, the head of the house was legally responsible for his wife's dowry and had the duty to preserve this asset so that the widow could take advantage of it after his death; an obligation, which has to be considered as a further restriction of the husband's autonomy 
and authority. ${ }^{1 x v i i i}$

\section{The duty to provide for one's family}

At this point we should ask how cultural models, and their corresponding social expectations, influenced the behaviour of individuals. Did those husbands who were unable to provide for their families and who depended on their wives' income feel inadequate and dishonoured?

Did the limits on the ability of urban male artisans to be self-supporting diminish their masculinity or does the material which has been presented here force us to reconsider our views on what masculinity entailed? Research published during the 1970s and 1980s on changes brought about by industrialisation in Great Britain and the United States has shown that unemployment could undermine the male identity as breadwinner. Moreover, it could further lessen his self-respect and his source of authority, and eventually, lead to tensions between the partners. ${ }^{\text {lxix }}$ In Old Regime Turin, the married man considered himself - and was perceived as - the head of the household and the main provider of his family. The population census, for example, carried out in 1802, was strongly affected by this cultural model: for local authorities in charge of compiling the census, as well as for individuals declaring their family situation, or house owners listing their tenants, the professional position of the husband/father/head of the household was judged sufficient in order to describe the whole set of economic activities of the family and as a guarantee of its respectability. ${ }^{\mathrm{lx}}$ Moreover, in spite of instability and incertitude of the labour market, male work did not lose social 
standing, as opposed to female labour which had no social acknowledgement. Tasks and qualities attributed to married men were therefore the result of an ideological and cultural construct, that coexisted with the incoherencies and irregularities tied to labour, the difficulties encountered in managing the family resources and the restrictions imposed on marital authority by the presence of the wife's own assets and work. Scholars have perhaps over-emphasised the impact of the pater familias model to the detriment of another value, which was widespread among the Turinese middle and lower social groups: the idea that everyone had the duty to provide for his own as well as for the sustenance of the family. An eloquent example is found in the statute of the Ospedale di Carità, established in June 1700: the institution would shelter individuals who 'due to their young age or old age are not able to gain their livelihood and do not have funds, income and other goods, (...) or a family member, that is father, mother, sons, daughters, brothers or sisters (...) in condition to offer them relief'. ${ }^{1 x x i}$ In addition, the Ospedale would assist families with numerous children who 'could not be maintained by the head of the household or (...) because the labour of the father and mother are not sufficient to provide for them'. Allegedly, therefore, both partners (and broadly speaking all the members of the household) were in charge of the survival of their partner/children/siblings. This principle suggests that there were different ideals or expectations when it came to spousal co-operation, that competed with - and even overrode the pater familias norm. The idea that all the members of the domestic unit had to contribute to their kindred is already confirmed by the fact that bachelor journeymen applying to the 
king justified their request analogously to the married artisans previously described, appealing to the responsibility to support their natal kin rather than wives and children. Benedetto Forneris, for example, asked to be admitted to the mastery of spirit and candymakers in order to provide for himself, his parents (who were over 60 years of age) and his five younger siblings (three brothers and two sisters). ${ }^{\text {1xxii }}$ While in 1784 Felice Martin, asked for a reduction of fees 'with the aim to offer some education to his nephews', who were orphans and had been placed under his responsibility. ${ }^{\text {lxxii }}$

This specific economic responsibility attributed to all the members of the family who were able to work, was rooted in the law of alimenta (the duty to provide for the maintenance of one's own relatives). The law of alimenta was established in Roman Law and discussed by jurists through the Middle Ages and the Renaissance. ${ }^{\text {xxiv }}$ This principle had been concealed by the monolithic ideology of the pater familias but ultimately did not lose importance among the Turinese middle and lower social groups, thus mitigating the primacy of the 'male provider' model. Of course, this should not lead us to underestimate the difficulties encountered by women in the labour market: in several contexts they suffered economic invisibility, marginalisation, salary disparity and exploitation, and undoubtedly the strong rhetorical power of the patriarchal ideology masked the daily - and more complex and ambiguous - experience of men and women, fully involved in ensuring an income and avoiding economic destitution. 


\section{Conclusion}

The aim of this article was to investigate the role of married men from middle and lower classes in the family economies of eighteenth-century Turin. According to the conduct books as well as much scholarship, the husband/father was expected to be the pater familias, to act as the main provider and the economic leader of the household. Moreover he was required to attain economic and professional independence. This research offers evidence of the fact that in Turin these tasks were part of an ideological and cultural construct, rather than the concrete experience of all adult men. Yet the article argues that in eighteenth-century Turin the male identity resulted from the specific economic, social and cultural factors and from a complex division of labour within the household.

The registers of the Ospedale di Carità, as well as the petitions of artisans, clarify that husbands and fathers were not always able to ensure a regular income, or to achieve professional independence. Neither could the husband always act as the economic leader of the household, nor were the labour relationships between the spouses based on a rigid genderbased hierarchy. First, there is evidence that in eighteenth-century Turin the position of master/journeyman was not automatically connected to marital status as several models of masculinity (in northern and in southern Europe) let us presume. Moreover male work did not necessarily lead to economic stability since pluriactivity, professional and geographical mobility were common experiences among workers. On the other hand, the wife could collaborate in the family business and invest her dowry in it or she could perform a related 
(or semi-related) activity and eventually act as the sole provider. As a consequence, it is likely that the husband's marital authority - at least the prestige which derived from his economic position - was subject to restrictions: the husband's professional identity was blurry, he was obliged to take into account his wife's opinion and he was also legally responsible for the integrity of his wife's capital. In addition, specific local conditions - such as the economic and social crisis which struck the city in the second half of the century - further aggravated the precariousness and uncertainty of men's economic roles. Finally this article has shown that, even if in some contexts a married man continued to consider himself - or was perceived as - the main provider (i.e. in population censuses), actually the Turinese model of masculinity was in competition with another coexisting and popular ideology - based on evidence of legal code and recognised also by authorities - which strongly mitigated the male economic leadership, and acknowledged that both spouses held responsibility for the survival of the family. This cultural and economic model has been seldom neglected by the research; however the Turinese case demonstrates that because of its heuristic power, it is undoubtedly worthy to be taken into account and discuss in future research.

i John Tosh, A Man's Place. Masculinity and the Middle-class Home in Victorian England (New Haven: Yale University Press, 1999); Elisabeth Foyster, Manhood in Early Modern 
England: Honour, Sex and Marriage (London: Longman, 1999); Alexandra Shepard, Meaning of Manhood in Early Modern England (Oxford: Oxford University Press, 2003). For German-speaking countries see: Merry E. Wiesner, 'Corpi separati. Le associazioni dei lavoranti nella Germania moderna', Memoria 27 (1989), pp. 44-67; Merry E. Wiesner, 'Wandervogels and women: journeymen's concepts of masculinity in early modern German', Journal of Social History, 24, (1991), pp. 767-82; Joseph Ehmer, “"Servi di donne”. Matrimonio e costituzione di una propria famiglia da parte dei garzoni come campo di conflitto nel mondo artigiano mittelereuropeo', Quaderni Storici 80 (1992), pp. 475-507. For Italy see: 'Uomini', Memoria. Rivista di storia delle donne, Special Issue 27 (1989); Simonetta Piccone Stella and Chiara Saraceno (eds), Genere. La costruzione sociale del femminile e del maschile (Bologna: Il Mulino, 1996); Sandro Bellassai and Maria Malatesta (eds), Genere e mascolinità. Uno sguardo storico (Roma: Bulzoni, 2000); Angiolina Arru (ed.), La costruzione dell'identità maschile nell'età moderna e contemporanea (Roma: Biblink, 2001); Angiolina Arru (ed.), Pater familias (Roma: Biblink, 2002); Alessandra Pescarolo and Elisabetta Vezzosi (eds) 'Mascolinità', Genesis. Rivista della società italiana delle storiche, Special Issue 2 (2003); Raffaella Sarti, 'The true servant: Self-definition of male domestics in an Italian city (Bologna, 17th-19th centuries)', The History of the Family 10 (2005), pp. 407-33; Sandra Cavallo, Artisans of the Body in Early Modern Italy. Identities, Families and Masculinities (Manchester: Manchester University Press, 2007); Elena dell'Agnese and Elisabetta Ruspini (eds), 
Mascolinità all'italiana: costruzioni, narrazioni, mutamenti (Torino: UTET, 2007).

ii Daniela Frigo, Il padre di famiglia: governo della casa e governo civile nella tradizione dell'economia tra cinque e Seicento (Roma: Bulzoni, 1985); Renata Ago, 'La costruzione dell'identità maschile: una competizione tra uomini’ in Angiolina Arru (ed.), La costruzione dell'identità, pp. 17-30; Marco Cavina, Il padre spodestato. L'autorità paterna dall'antichità a oggi (Roma-Bari: Laterza, 2007) .

iii John Tosh, 'Men in the Domestic Sphere: A Neglected History', in Angiolina Arru, (ed.), La costruzione dell'identità, pp. 47-61, p. 48.

iv Tosh, 'Men in the Domestic Sphere: A Neglected History', p. 50.

v Merry E. Wiesner, Corpi separati; Joseph Ehmer, 'Servi di donne'; James Farr, Hands of Honor: Artisans and their World in Dijon, 1550-1650 (Ithaca: Cornell University Press, 1988); James Farr, Artisans in Europe 1300-1914 (Cambridge: Cambridge University Press, 2000); Geoffrey Crossick (ed.), The Artisan and the European Town, 1500-1900 (Aldershot: Ashgate, 1997).

vi Merry E. Wiesner, Wandervogels and women, p. 776; Merry E. Wiesner, Corpi separati; Joseph Ehmer, 'Servi di donne'. A very useful survey on the topic which takes into consideration several European areas: Raffaella Sarti, 'Nubili e celibi tra scelta e costrizione. I percorsi di Clio', in Margareth Lanzinger and Raffaella Sarti (eds), Nubili e celibi tra scelta e costrizione (secoli XVI-XX) (Udine: Forum, 2006), pp. 144-319.

vii Steven L. Kaplan, 'Les corporations, les "faux ouvriers" et le faubourg Saint-Antoine au 
XVIII' siècle', Annales ESC 1988, pp. 353-378; Alain Thillay, Le faubourg Saint-Antoine et ses faux ouvriers. La liberté du travail à Paris au XVIIe et XVIIIe siècle (Champ Vallon: Seyssel, 2002).

viii Edward J. Jr. Shephard, 'Social and Geographic Mobility of the Eighteenth-Century Guild Artisan: an Analysis of Guild Reception in Dijon, 1700-90', in Steven Kaplan and Cynthia Koepp (eds), Work in France. Representation, meaning, organization and practice (Ithaca: Cornell University, 1986), pp. 97-130; Michael Sonenscher, The Hatters of Eighteenthcentury France (Berkley: University of California Press, 1987).

ix An explicit effort to renew studies on pre-industrial labour (especially male work) has been carried out in the following Special Issue: Eleonora Canepari and Beatrice Zucca Micheletto (eds), 'Le travail comme resource', Mélanges de l'École Française de Rome, Italie Mediterranée 123 (2011).

x Alexandra Shepard, 'Manhood, Credit and Patriarchy in Early Modern England c. 15801640', Past and Present 167 (2000), pp. 75-106, p. 106.

xi Ida Fazio, 'Valori economici e valori simbolici. Il declino della dote nell'Italia dell'Ottocento', Quaderni Storici (79) 1992, pp. 291-316; Angela Groppi, 'Lavoro e proprietà delle donne in età moderna', in Angela Groppi (ed.), Il lavoro delle donne (Roma-Bari: Laterza, 1996), pp. 119-163.

xii Sandra Cavallo, Artisans of the Body, pp. 211-213; Sandra Cavallo, 'Bachelorhood and masculinity in Renaissance and Early Modern Italy', European History Quarterly, Special 
Issue: Unmarried lives: Italy and Europe, Sixteenth to Nineteenth Centuries, Silvia Evangelisti, Margareth Lanzinger, Raffaella Sarti (eds) 38 (2008), pp. 375-397.

xiii For specific research on the history of the Ospedale di Carità see: Sandra Cavallo, Charity and Power in Early Modern Italy: Benefactors and Their Motives in Turin 1541-1789 (Cambridge: Cambridge University Press,1995); Sandra Cavallo, 'Patterns of Poor Relief and Patterns of Poverty in Eighteenth-Century Italy: the Evidence of the Turin Ospedale di Carità', Continuity and Change 5 (1990), pp. 65-98; Margaret Moody, The Royal Poorhouse in $18^{\text {th }}$ Century Turin, Italy: the King and the Paupers (Lewiston: Edwin Mellen Press, 2001).

xiv Pietro Castiglioni, Relazione generale con una introduzione storica sopra i censimenti delle popolazioni italiane dai tempi antichi sino all'anno 1860. Vol. I. In Statistica del Regno d'Italia, Popolazione. Censimento degli antichi stati sardi (1 gennaio 1858)e censimenti di Lombardia, di Parma e di Modena (1857-1858) (Torino: Stamperia Reale, 1862).

xv The population census of 1802 underestimates individuals employed in the domestic services. Indeed, before the arrival of the Napoleonic army, the majority of servants escaped from Turin, following their aristocratic masters and families. The data contained in the census has been elaborated into a database by a research team at the University of Turin under the supervision of prof. M.C. Lamberti.

xvi Jean-Baptiste Colbert (1619-1683) served as the Minister of Finances of France from 
1665 to 1683 under the rule of Louis XIV. He carried out several reforms with the aim to improve and strengthen the French manufactures as well as to struggle against the concurrence of foreign products.

xvii Giuseppe Chicco, La seta in Piemonte 1650-1800 (Milano: F. Angeli, 1995).

xviii Sandra Cavallo, Charity and Power, p. 244.

xix Donatella Balani, Il Vicario tra città e stato. L'ordine pubblico e l'annona nella Torino del Settecento (Torino: Deputazione Subalpina di Storia Patria, 1987).

xx Archivio Storico del Comune di Torino (ASCT), Ospedale di Carità, cat. VI, Libri delle informazioni per ricoveri, vol. 40, f. 427.

xxi Archivio Storico del Comune di Torino (ASCT), Ospedale di Carità, cat. VI, vol. 39, f. 611.

xxii Archivio Storico del Comune di Torino (ASCT), Ospedale di Carità, cat. VI vol. 44, f. 183.

xxiii Archivio Storico del Comune di Torino (ASCT), Ospedale di Carità, cat. VI, vol. 44, f. 346.

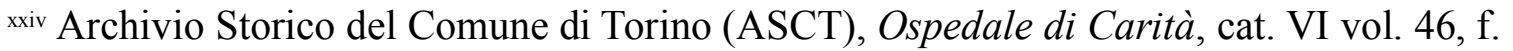
453.

xxv All the examples are drawn from the database of the poor that I have collected from the Libri delle Informazioni covering the period between 1766-1792.

${ }^{\text {xxi }}$ Merry E. Wiesner, Corpi separati; Joseph Ehmer, 'Servi di donne'; James Farr, Hands of 


\footnotetext{
Honor; John Tosh, A Man's Place.

xxvii Merry E. Wiesner, Corpi separati; Joseph Ehmer, 'Servi di donne'.

xxviii Simona Cerutti, Mestieri e privilegi. Nascita delle corporazioni a Torino. Secoli XVIIXVIII (Torino: Einaudi, 1992); Ester De Fort, 'Mastri e lavoranti nelle università di mestiere tra Settecento e Ottocento', in Aldo Agosti and Gian Mario Bravo (eds), Storia del movimento operaio, del socialismo e delle lotte sociali in Piemonte (Bari: De Donato, 1979), pp. 89-142.
}

xxix I went through all the registers of these crafts. Petitions relative to the period between 1748-1795 amount to about one hundred.

${ }^{x x x}$ Archivio di Stato di Torino (AST), sez. riun., Consolato di Commercio, Calzolai, vol. 10, ff.nn.

xxxi Archivio di Stato di Torino (AST), sez. riun., Consolato di Commercio, Parrucchieri, vol. 34, ff. n.n.

xxxii Data drawn from the cross reference of the census of Turinese artisans (carried out 1792) and the population census of the city (1802). AST, I sez., Commercio, II add., Magistrato del Consolato, m. 2, Volume contente li nomi, cognomi e patria de' mastri e padroni e de' loro rispettivi lavoranti ed apprendizzi delli arti e mestieri, 1792.

xxxiii Sandra Cavallo, Artisans of the Body, chap. 6.

xxxiv AST, sez. riun., Consolato di Commercio, Registro de Privilegj e Patenti Erezione dell'Università de Confettieri e d'Acquavitai di questa città, vol. 1, ff. 25v-26v. 
${ }^{x x x}$ AST, sez. riun., Insinuazione di Torino, a. 1758, 1. 2, c. $2 r-3 v$; Consolato di Commercio, Registro dei Capellaj, vol. 11, ff. 306v-307r.

xxxvi $\quad$ AST, sez. riun., Notai di Torino, vol. 2778, f. $1 r-16 r$.

xxxvii Despite its importance, the topic has seldom been tackled by researchers, especially for urban contexts. Alain Cottereau, 'Précarité, économies familiales et projets de vie', in Alain Cottereau, Maurizio Gribaudi, (eds), Précarités, cheminements et formes de cohérence sociale au XIX siècle (Paris: Ed. EHESS, 1999), pp. 1-85; Thomas Pfrisch, 'Artisans et pluriactivité. L'exemple de Dijon à la fin du Moyen Age', Histoire Urbaine 6 décembre (2002), pp. 5-22. About pluriactivity among servants: Elisabeth Ewan, 'Mistresses of themselves? Female domestic servants and by-employments in sixteenthcentury Scottish towns', in Antoinette Fauve-Chamoux (ed.), Domestic Service and the Formation of European Identity: understanding the globalization of domestic work, 16th21st centuries (Bern: Peter Lang, 2004), pp. 411-433, also published in Suzy Pasleu and Isabelle Schopp (eds), with Raffaella Sarti, Proceedings of the Servant Project (Liège: Éditions de l'Université de Liège, 2005), vol. 4, 25-45. I am thankful to R. Sarti for this information.

xxxviii AST, sez. riun., Consolato di Commercio, Calzolai, vol. 9, f. n.n.

xxxix ASCT, Vicariato, Atti Criminali Sommari, vol. 127, ff. 156r-v.

xl AST, I sez., Commercio, m. 1 bis, Calzettaj.

xli AST, I sez., Commercio, m. 1 bis, Calzettaj, I archiviazione, Manifatture e fabbricazioni, 
m. 1, Negosianti et artisti della presente città di Torino, 1742.

xlii Margaret Pelling, 'Occupation diversity: barbers surgeons and the trade of Norwich, 1550-1640', Bulletin of the History of Medicine, 56-4 (1982), pp. 484-511. See also S. Cavallo, Artisans of the body chap. 1 and 2.

xliii See footnote 30 .

xliv AST, sez. riun., I archiviazione, Manifatture e fabbricazioni, m. 1, Negosianti et artisti.

xlv Merry E. Wiesner, Wandervogels and women; Ead., Corpi separati; James Farr, Hands of Honor.

xlvi Ibid., Consolato di Commercio, Capellaj, vol. 11, ff.n.n.

xlvii Among the most interesting studies on the topic see: Barbara Hanawalt (ed.), Women and work in preindustrial Europe (Bloomington: Indiana University Press, 1986); Daryl Hafter, Women at work in preindustrial France (University Park, Pennsylvania: The Pennsylvania State University Press, 2007). For Italy see: Angela Groppi (ed), 'Il lavoro delle donne; Genesis. Rivista della Società Italiana delle Storiche', Flessibili/Precarie Special Issue VII, 1-2 (2008), Anna Bellavitis and Simonetta Piccone Stella (eds). xlviii Alice Clark, Working life of the women in the seventeenth century (London: Routledge, 1919).

xlix About spousal partnership see: Natalie Zemon Davis, 'Women in crafts in sixteenthcentury Lyon' in Barbara Hanawalt (ed.) Women and work, pp. 167-197; Angela Groppi, 'Lavoro e proprietà delle donne in età moderna', in Angela Groppi (ed.), Il lavoro delle 
donne, pp. 119-163; Danielle Van Den Heuvel and Elise Van Nederveen Meerkerk (eds) 'Partners in business' Special Issue, Continuity and Change, 23 (2008) and Alexandra Shepard, 'The worth of married women in the English church courts, c. 1550-1730', in Cordelia Beattie and Matthew Frank Steven (eds), Married women and the law in premodern Northwest Europe (Woodbridge: The Boydell Press, 2013), pp. 191-211. About unpaid work performed by women in family businesses see: Anna Bellavitis and Manuela Martini (eds), 'Households, family workshops and unpaid market work in Europe from the $16^{\text {th }}$ century to the present' The History of the Family, Special Issue, 19 (2014).

1 AST, sez. riun., Consolato di Commercio, Registro dei Tafferieri, vol. 67, ff. 281r-285v.

li AST, sez. riun., Notai di Torino, vol. 2755, ff. 216r-v.

lii Number of couples for whom the job of the husband and of the wife is known. Housewives (women who declared that taking care of their home and children was their only occupation) have not been calculated in this percentage (474 individuals).

liii AST, sez. riun., Consolato di Commercio, Bindellaj, vol. 37, ff. 1r-3v.

liv AST, sez. riun., Bottonai, vol. 6, ff. nn.

Iv AST, sez. riun., Consolato di Commercio, Registro dei Taffetieri, vol. 66, ff. 82r-84r.

lvi Jane Humphries, Carmen Sarasúa, 'Off the Record. Reconstructing Women's Labor Force Participation in the European Past', Feminist Economics 18 (2012), pp. 39-67. In Turin, applicants at the Ospedale di Carità were encouraged to declare with precision the job of all the members of the family in order to prove their condition of 'deserving poor'. 
Beatrice Zucca Micheletto, 'Reconsidering women's labor force participation rates in eighteenth-century Turin', Feminist Economics, 19 (2013), pp. 200-223.

lvii On the dowry system in Turin and the Piedmont see Gian Savino Pene Vidari, 'Osservazioni sui rapporti patrimoniali fra coniugi nel Piemonte del sec. XVIII', Rivista di Storia del Diritto Italiano, 54 (1980-1981), pp. 19-60; Gian Savino Pene Vidari, 'Dote, famiglia e patrimonio fra dottrina e pratica in Piemonte', in La famiglia e la vita quotidiana in Europa dal '400 al '600, Proceedings of the international workshop Milan December 1983 (Roma: Ministero dei Beni Culturali, 1986), pp. 109-121.

lviii In early modern Italy the legal framework of the dowry was partly the outcome of a revival of the Roman law during the eleventh century and partly a result of the influence of Germanic law which partially modified the nature of this asset. Marco Bellomo, Ricerche sui rapporti patrimoniali tra coniugi (Milano: Giuffré, 1961).

lix The Regie Costituzioni regulated the religious, political and economical life of all the subjects of Piedmont and established the basis for civil and criminal justice. Chapter 5 was dedicated to the inheritance and property rights of 'minors' (women, children) and regulated also dowry alienation.

Ix The use of the dowry in situations of economic hardship has been noticed also by Ida Fazio for preindustrial Sicily (Ida Fazio, Valori economici e valori simbolici).

Ixi I have studied in detail dowry and dowry alienations in chapters 2 and 3 of my book: Beatrice Zucca Micheletto, Travail et propriété des femmes en temps de crise (Turin, 
XVIII siècle) (Mont-Saint-Aignan: Presses Universitaires de Rouen et du Havre, 2014). The dowry could be used for one or more purposes at the same time: this has been taken into account in calculating the percentages. Because of this the total of the percentages is more than hundred.

lxii AST, sez. riun., Notai di Torino, vol. 2773, f. 209r; ibid., ff. 152r-153v.

1xii AST, sez. riun., Notai di Torino, vol. 2765, ff. 354r-360r; AST, sez. riun., Notai di Torino, vol. 2774 , ff. $297 r-302 v$.

lxiv AST, sez. riun., Notai di Torino, vol. 2777, ff. 349r-359v.

Ixv Sandra Cavallo, 'Una fonte per lo studio dei rapporti famigliari intra e inter-generazionali', in Anna Bellavitis and Isabelle Chabot (eds), Famiglie e poteri in Italia tra Medioevo ed Età Moderna (Roma: École Française de Rome, 2009), pp. 327-350; Sandra Cavallo, 'Fatherhood and the non-propertied classes in Renaissance and Early Modern Italian towns', The History of the Family 2 (2012), pp. 1-17; Sandra Cavallo, Artisans of the body.

${ }^{\text {Ixvi }}$ AST, sez. riun., Atti di società, vol. 1, f. 5r.

Ixvii In several Italian cities the male weavers were dependent on their wives' assets, since the latter owned the looms, bought thanks to their dowries (Angela Groppi, Lavoro e proprietà delle donne, pp. 119-163, especially pp. 147-148).

lxviii As already suggested by Ida Fazio for the Sicilian case, in Turin, in a long-term perspective, the employment of the dowry in survival strategies weakened the wife and her 
assets. Of course, the dowry invested in the family business was guaranteed but after the husband's death, the widow could hardly recover her capital. My research on the notarial deeds shows that among artisans the dowry remained invested in the shop and that widows had to make arrangements to take advantage of it (Beatrice Zucca Micheletto, Travail et propriété des femmes, chap. 3).

lxix Lydia Morris, The workings of the household (Cambridge: Polity Press 1990).

Ixx Beatrice Zucca Micheletto, Reconsidering women's labor force.

Ixxi Deliberazione della congregazione dell'ospedale della Carità di Torino, colla quale, stante un dono fattosi da SAR, determina di accettarvi tutti i poveri mendicanti in Torino, e stabilisce le regole pella loro accettazione ed occupazione, per impedire la mendicità e per l'economia della casa, in Felice Amato Duboin, Raccolta per ordine di materie delle leggi, cioè patenti, manifesti ecc.. pubblicate sino all'8 dicembre 1789 sotto il felicissimo dominio della Real Casa di Savoia (...) (Torino: Marcio Tip., 1818-1869), Libro VII, Titolo XIX, cap. I, pp. 271-275.

Ixxii AST, sez. riun., Consolato di Commercio, Registro de Privilegj e Patenti Erezione dell'Università de Confettieri e d'Acquavitai di questa città, vol. 1, ff. 66r-74r. Ixxiii AST, sez. riun., Consolato di Commercio, Registro de Privilegj e Patenti Erezione dell'Università de Confettieri e d'Acquavitai di questa città, vol. 1, ff. 96r-v.

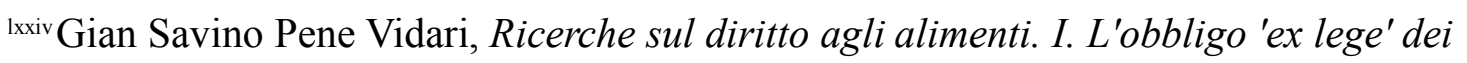
familiari nei giuristi dei secc. XII-XIV (Torino: Giappichelli, 1972). The topic has been 
explicitly analysed in a recent and pioneer work by Angela Groppi, Il welfare prima del welfare. Assistenza alla vecchiaia e solidarietà tra generazioni a Roma in età moderna (Roma: Viella 2010). 